\title{
Selection of Rice Herbicide from Several Sulfonylurea Compounds
}

\author{
Shunji Takeda, Takeshi Yuyama, \\ Robert C. Ackerson* and Russell C. WeIgeL** \\ Agricultural Science Laboratory, Agrichemicals Divison, Du Pont Japan Ltd. \\ Kashiwada 856, Ushiku, Ibaraki 300-12, Japan
}

\section{Introduction}

Sulfonylurea herbicides were di scovered and developed by E. I. du Pont du Nemours and Co., Inc. Some of the compounds are chlorsulfuron $^{2 \sim 6)}$ (DPX-W4189, Glean ${ }^{\circledR}$ ) and metsulfuron methyl ${ }^{1)}$ (DPX-T6376, Ally ${ }^{\circledR}$ ) for cereals, sulfometuron methyl ${ }^{3)}(\mathrm{DPX}-5648$, Oust $\left.{ }^{\circledR}\right)$ for noncropland and DPX-F6025 (Classic $\left.{ }^{\circledR}\right)$ for soybeans.

We have synthesized and evaluated many sulfonylurea compounds. Many of them showed distinct selectivity between the grasses and broad leaves. ${ }^{1,2,4,6)}$ Although many of the tested sulfonylureas exhibited very good herbicidal activity, most are not sufficiently selective for use in early growth stage of rice.

Sulfonylurea compounds are considered as combinations of three moieties: an aryl group, a sulfonylurea bridge and a heterocycle.

After investigating many of these compounds for biological activity, it has been indicated that the herbicidal activity and crop safety are closely related to the chemical structure, especially to variations of the substitute in aryl moiety. ${ }^{3)}$

In the following paper, we introduce DPXF5384 as a highly active and selective herbicide for use in rice paddies. DPX-F5384 was selected from a number of sulfonylureas because this particular compound was found to have the necessary balance between activity and selectivity based on structure-activity relationships and biological performance.

The structure-activity relationships of sulfonylureas, especially of aryl moieties including the phenyl, phenoxy and benzyl groups are described.

\section{Materials and Methods}

\section{(1) Compounds}

The test compounds are shown in Table 1.

Table 1 DPX-F5384 and its analogs<smiles>[R]N[14CH2]N[R16]([R])=O</smiles>

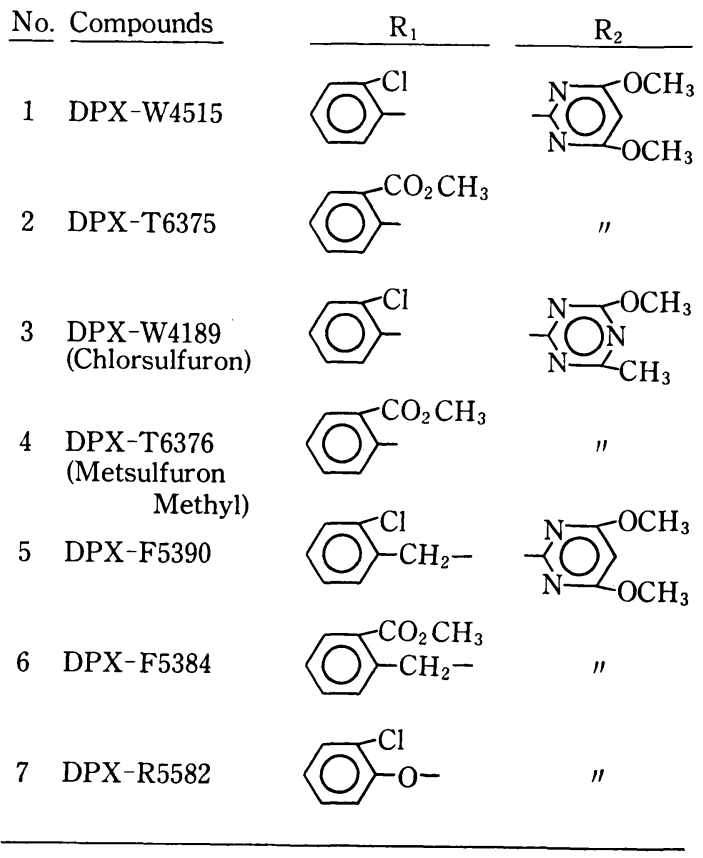

* Agricultural Chemicals Department, E. I. du Pont de Nemours \& Co. Inc., Wilmington, Delaware 19898, U.S. A.

** Department of Botany, University of Tennessee, Knoxville, Tennessee 37966, U. S. A. 
The structural difference of these compounds is found in the aryl moiety and substituent at 2-position of the aryl moiety. DPX-W4515, DPX-T6375, DPX-W4189 (Chlorsulfuron), and DPX-T6376') (Metsulfuron methyl) have a phenyl group while DPX-R5582 has a phenoxy group, and DPX-F5390 and DPXF5384 a benzyl group. DPX-W4515, DPXR5582, and DPX-F5390 have an orthochloro substituent in the aryl moiety, while DPXT6375 and DPX-F5384 have a carbomethoxy group.

These compounds were produced by the reactions of corresponding arylsulfonyl isocyanates with the appropriately substituted heterocycle amine. The purity of the test compounds was approximately 97 percent. The compounds were dissolved in acetone or acetone- $\mathrm{H}_{2} \mathrm{O}(1: 1)$ for testing purposes. These solutions were diluted by distilled water to prepare each concentration shown in Table 2 in a petri dish test. The compounds dissolved in acetone at tested rates were applied by pipette in a Wagner pot test.

\section{(2) Petri Dish Tests}

Filter papers were placed in $9 \mathrm{~cm}$ petri dishes. Stock solution of each compound was added $20 \mathrm{ml}$ by rice and Chinese cabbage, and $30 \mathrm{ml}$ in the case of Urikawa into petri dishes. Fifteen rice seeds (Oryza sativa cv. Nihonbare), 15 Chinese cabbage (Brassica pekinensis) seeds and 7 tubers of Urikawa (Sagittaria pygmaea) were placed in each petri dish. The dishes were then placed in an incubator controlled at $28^{\circ} \mathrm{C}$ with 7,000 lux of illumination. After 7 to 9 days, the length of the shoots and roots was measured. The data are the mean values of three replications and are presented as a percent of untreated check.

\section{(3) Pot Test}

The Wagner pot tests to determine herbicidal activity and rice selectivity were conducted in a greenhouse with a simulated paddy environment and temperatures controlled at
25 to $27^{\circ} \mathrm{C}$ during the day (7 19 o'clock) and 16 to $18^{\circ} \mathrm{C}$ at night.

\section{1) Herbicidal Activity}

The paddy soil (alluvium clay loam, O. M. $=5.16 \%)$ in the plastic Wagner pot (200 $\mathrm{cm}^{2}$ ) was applied with $1.5 \mathrm{~g}$ of fertilizer ( $\mathrm{N}$. P. K, 15-15-15) per pot. Weed seeds and tubers were incorporated into the surface layer of the soil. Water was added to each pot to a depth of $3 \mathrm{~cm}$ above the soil level and this depth was maintained throughout the test. An acetone solution of each compound was applied by pipette soon after weed emergence. Approximately 25 days after application, control of the weeds was visually rated.

\section{2) Safety Test For Rice Plants}

Following the procedures outlined above, soil (alluvium clay loam, O. M. $=5.16 \%$ ) was put into the same pots and then fertilized (N. P. K, 15-15-15, 1.5g/pot), puddled and watered. Rice seedlings (cv. Nihonbare) at the 2-leaf stage were transplanted at the rate of 4 plants/pot. Compounds were applied 3 days after transplanting. The pots were placed in the greenhouse for 20 days before crop injury was rated. Plant height and dry weight of the above-the-soil parts were determined.

Both weed control and phytotoxicity were evaluated by a rating system of zero to 10 , zero standing for no effect and 10 representing complete kill.

\section{Results}

\section{(1) Petri Dish Tests}

As shown in Table 2, DPX-T6375 and DPX-F5384 affected root elongation of the treated plants. Inhibition of shoot elongation was not observed in Chinese cabbage because the length of stems was not affected by the compounds up to the cotyledon stage of growth. Mode of action studies of chlorsulfuron by $\mathrm{Ray}^{5)}$ have indicated that chlorsulfuron at $0.001 \mathrm{ppm}$ inhibited the growth of corn root, while the same at $0.01 \mathrm{ppm}$ inhibited 
Table 2 Effects of two sulfonylureas substituted with $2-\mathrm{CO}_{2} \mathrm{CH}_{3}$ in aryl moiety on rice, $\mathrm{Ch}$ inese cabbage and $S$.pygmaea

\begin{tabular}{|c|c|c|c|c|c|c|c|}
\hline \multirow{2}{*}{$\begin{array}{l}\text { Com- } \\
\text { pounds }\end{array}$} & \multirow{2}{*}{$\mathrm{ppm}$} & \multicolumn{2}{|c|}{ O. sativa } & \multicolumn{4}{|c|}{ B. Pekinensis S.pygmaea } \\
\hline & & $\mathrm{S}$ & $\mathrm{R}$ & S & $\mathrm{R}$ & S & $\mathrm{R}$ \\
\hline \multirow{3}{*}{$\begin{array}{l}\text { DPX- } \\
\text { T6375 }\end{array}$} & $5 \times 10^{-3}$ & 12 & 10 & 100 & 17 & 61 & 18 \\
\hline & $5 \times 10^{-4}$ & 65 & 36 & 107 & 18 & 90 & 46 \\
\hline & $5 \times 10^{-5}$ & 100 & 115 & 105 & 50 & 94 & 87 \\
\hline \multirow{4}{*}{$\begin{array}{l}\text { DPX- } \\
\text { F5384 }\end{array}$} & $5 \times 10^{-1}$ & 73 & 21 & - & - & 一 & - \\
\hline & $5 \times 10^{-2}$ & 80 & 40 & 107 & 17 & 81 & 16 \\
\hline & $5 \times 10^{-3}$ & 100 & 103 & 100 & 38 & 80 & 50 \\
\hline & $5 \times 10^{-4}$ & - & - & 110 & 82 & 89 & 58 \\
\hline
\end{tabular}

Length of shoot \& root: \% of untreated check $\mathrm{S}$ : Shoot, R : Root

the shoot growth. Similar action was observed in this test and sensitivity of plant roots to both DPX-T6375 and DPX-F5384 was higher than that of shoot. DPX-T6375 inhibited the root elongation of rice, Chinese cabbage and Urikawa at a concentration of $5 \times 10^{-4} \mathrm{ppm}$. DPX-T6375 at $5 \times 10^{-5}$ did not affect the root growth of rice but retarded that of the other two plants.

On the other hand, DPX-F5384 at $5 \times 10^{-3}$ ppm caused no effect on rice. DPX-F5384 inhibited root growth, even at $5 \times 10^{-4} \mathrm{ppm}$ in Chinese cabbage and Urikawa.

In this experiment, the difference in sensitivity between rice, Chinese cabbage and Urikawa to DPX-F5384 was clearly exhibited with respect to root growth. Also, relatively weak selectivity was observed at an extremely low concentration of DPX-T6375.

These results suggest that DPX-T6375 is relatively less selective than DPX-F5384 between rice and broadleaf plants.

\section{(2) Herbicidal Activity}

Five pyrimidine derivatives and two triazine derivatives were tested to compare herbicidal activity. As shown in Table 3, both No. 1 (DPX-W4515) and No. 2 (DPX-T6375) exhibited high activity on annual and perennial weeds at rates as low as $2 \mathrm{~g}$ a. i./ha. Number 4 (DPX-T6376) as low as $4 \mathrm{~g}$ a. i./ha, exhibited activity equivalent to the above two
Table 3 Herbicidal activity of DPX-F5384 and its analogs

\begin{tabular}{|c|c|c|c|c|c|c|c|c|}
\hline \multirow{2}{*}{ No. } & \multirow{2}{*}{ Compounds } & \multirow{2}{*}{$\begin{array}{l}\text { Rate g } \\
\text { a.i./ha }\end{array}$} & \multicolumn{6}{|c|}{ Herbicidal Activity* } \\
\hline & & & Eo & $\mathrm{Cd}$ & $\mathrm{Cs}$ & $\mathrm{Sj}$ & $\mathrm{Sp}$ & $\mathrm{Bl}$ \\
\hline \multirow[t]{2}{*}{1} & DPX-W4515 & 1 & 7 & 9.5 & 9 & 10 & 9 & 10 \\
\hline & & 2 & 8 & 10 & 9.5 & 10 & 9.5 & 10 \\
\hline \multirow[t]{2}{*}{2} & DPX-T 6375 & 1 & 8 & 9.5 & 8 & 9 & 7 & 10 \\
\hline & & 2 & 9 & 9.5 & 10 & 9.5 & 8 & 10 \\
\hline \multirow[t]{2}{*}{3} & DPX-W4189 & 2 & 9.5 & 2 & 2 & 3 & 9 & 10 \\
\hline & & 4 & 9.5 & 3 & 4 & 5 & 9 & 10 \\
\hline \multirow[t]{2}{*}{4} & DPX-T 6376 & 2 & 8 & 10 & 7 & 9 & 9 & 10 \\
\hline & & 4 & 8 & 10 & 8 & 10 & 9 & 10 \\
\hline \multirow[t]{2}{*}{5} & DPX-F 5390 & 40 & 2 & 5 & 5 & 0 & 5 & \\
\hline & & 80 & 3 & 8 & 5 & 0 & 7 & 10 \\
\hline \multirow[t]{2}{*}{6} & DPX-F 5384 & 20 & 4 & 10 & 10 & 9 & 9 & 10 \\
\hline & & 40 & 7 & 10 & 10 & 10 & 9.5 & 10 \\
\hline \multirow[t]{2}{*}{7} & DPX-R5582 & 40 & 2 & 8 & 7 & 2 & 8 & 10 \\
\hline & & 80 & 4 & 10 & 9 & 6 & 9 & 10 \\
\hline
\end{tabular}

* 0 10 rating scale, Eo: Echinochloa oryzicola,

$\mathrm{Cd}$ : Cyperus difformis, Cs: Cyperus serotinus, $\mathrm{Sj}$ : Scirpus juncoides, Sp : Sagittaria pygmaea, $\mathrm{Bl}$ : Broadleaf weeds

compounds. Number 3 (DPX-W4189) provided the best control on Echinochloa oryzicola, but was weak on Cyperus difformis, Scirpus juncoides and Cyperus serotinus. Higher rates of the compound would be needed to give sufficient control of these Cyperaceae weeds.

Number 6 (DPX-F5384) and No. 5 (DPXF5390) were tested at the rate of 20 to $40 \mathrm{~g}$ and 40 to $80 \mathrm{~g}$ a. i./ha, respectively. Number 6 was highly effective on both annual and perennial weeds, but was not so active on Echinochloa oryzicola; No. 5 was much less active than No. 6.

Number 7 (DPX-R5582) showed relatively high activity on rice paddy weeds; however, it was less effective on Scirpus juncoides than No. 6.

\section{(3) Safety Test for Rice Plants}

The test results are shown in Table 4. As suggested by the results of the petri dish test, four compounds with a phenyl group, i. e., Nos. 1, 2, 3 and 4, which provided extraordinarily high herbicidal activity in the previous test, caused serious injury to 
Table 4 Safety of DPX-F5384 analogs for plants

\begin{tabular}{lcrrrr}
\hline \multirow{2}{*}{ No. Compounds } & \multirow{2}{*}{$\begin{array}{c}\text { Rate } \\
\text { a.i./ha }\end{array}$} & \multicolumn{3}{c}{ Rice Injury } \\
\cline { 4 - 6 } & V. C. & P. H. * & D. W. * \\
\hline 1 & DPX-W4515 & 2 & 5.5 & 81 & 61 \\
& & 4 & 7 & 73 & 48 \\
2 & DPX-T6375 & 2 & 7 & 53 & 45 \\
& & 4 & 8 & 43 & 24 \\
3 & DPX-W4189 & 2 & 3 & 87 & 81 \\
& & 4 & 5.5 & 66 & 54 \\
4 & DPX-T6376 & 2 & 3 & 85 & 76 \\
& & 4 & 4 & 80 & 69 \\
5 & DPX-F 5390 & 80 & 0 & 102 & 108 \\
& & 160 & 0 & 101 & 101 \\
6 & DPX-F 5384 & 40 & 0 & 99 & 95 \\
& & 80 & 2 & 95 & 90 \\
7 & DPX-R5582 & 80 & 1 & 96 & 92 \\
& & 160 & 2 & 95 & 91 \\
\hline
\end{tabular}

V. C.: Visual Count $(0 \sim 10$ rating scale)

P. H. : Plant Height, D. W. : Dry Weight of Shoot

* \% of untreated check

transplanted rice.

Both Nos. 1 and 2 at as low as $2 \mathrm{~g}$ a. i./ha caused heavy injury to rice. The dry weight of the rice shoots was decreased significantly. Number 3 and No. 4 at rates of $4 \mathrm{~g}$ a. i./ha caused moderate to severe growth inhibition, resulting in obvious decreases in shoot dry weight. Number 6 and No. 7 exhibited selectivity between rice and broadleaf plants. Both compounds caused only slight growth retardation in rice plants, at rates of $80 \mathrm{~g}$ and $160 \mathrm{~g}$ a. i./ha, respectively. The results indicate that DPX-F5384 provides the highest safety margin, since No. 6 at $20 \mathrm{~g}$ a. i./ha was more effective and had a broader spectrum of weed control than No. 7 at $40 \mathrm{~g}$ a. i. /ha.

Although No. 5 at the tested rates did not cause any phytotoxicity to rice plants, their herbicidal activity was also markedly lower.

\section{Discussion}

LEVITT $^{3)}$ recently summarized structureactivity relationships of sulfonylurea as follows: The 4-methoxy-6-methyl, 4, 6-dimethyl and 4,6-dimethoxy pyrimidine derivatives have the highest activity, while substitution with higher alkoxy or a methylthio group reduces the activity considerably. In the aryl moiety, substitution at 2 -positions with halogen, alkyl and carbomethoxy groups results in the highest activity, while substitution at 3 and 5 positions decreases activity.

The present results indicate: (1) From the petri dish test, the herbicidal activities might vary depending on the aryl moieties. (2) The pot tests confirmed the above observation. Compounds with a phenyl moiety had high herbicidal activity but caused heavy injury to rice plants. (3) In contrast, the compounds with a phenoxy or a benzyl moiety showed remarkable crop safety. However, the herbicidal activity and weed control spectrum of these compounds were not acceptable with the exception of DPX-F5384. (4) Regarding the substituent in the aryl moiety, there were notable differences, particularly in Cyperaceae weed control between an ortho-chloro and a carbomethoxy at 2-position of the compounds with benzyl group and 4,6-dimethoxy pyrimidine and with phenyl group and 4-methoxy6-methyl triazine (DPX-F5390 and DPX-F 5384, DPX-W4189 and DPX-T6376, respectively.)

In essence, the sulfonylurea derivatives which have phenyl (No. 1, No. 3, No. 2, and No. 4), phenoxy (No.7), and benzyl moiety (No. 6 and No.5) were significantly different in their herbicidal activites and crop safety. The biological activities and corresponding structures of the tested compounds are summarized in Table 5 . Sulfonylurea derivatives having either a phenyl- or phenoxymoiety have shortcomings as desirable rice herbicides, the former, having less selectivity for rice and the latter, the weaker herbicidal activity.

DPX-F5384, which is a benzyl-sulfonylurea derivative, has high herbicidal activity on annual and perennial paddy weeds except Echinochloa oryzicola and is very safe on 
Table 5 Relationships between structure and biological activity.

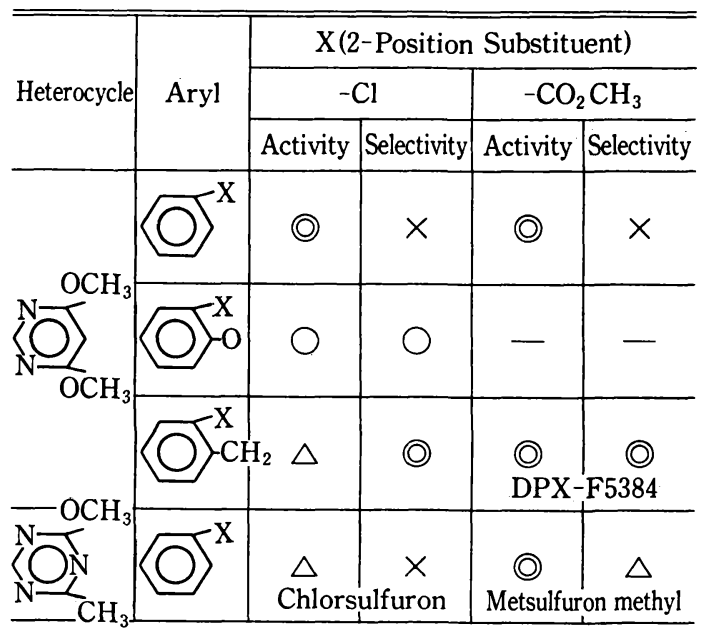

(2) Very High, $\bigcirc$ Acceptable, $\triangle$ Insufficient, $\times$ Very Low or None

rice. Consequently, DPX-F5384 is an excellent rice herbicide having the most appropriate balance between herbicidal activity and crop selectivity.

\section{Summary}

DPX-F5384, methyl 2-[C[C[[(4, 6-dimethoxpyrimidin-2-yl) amino] carbonyl] amino] sulfonyl]methyl]benzoate and several analogs were examined for herbicidal activities, crop safety, and selectivity.

(1) Both DPX-F5384 and DPX-T6375 which have substitutents of $2-\mathrm{CO}_{2} \mathrm{CH}_{3}$ were tested in petri dishes to examine their effect during early growth stage of rice, Brassica pekinensis and Sagittaria pygmaea. The results indicated that DPX-F5384 has the highest selectivity between rice and other plants. DPX-T6357 provided little selectivity.

(2) DPX-F5384 and the analogs were tested for herbicidal activity and crop safety under paddy rice conditions. DPX-W4515, DPX-T6375, DPX-W4189, and DPX-T6376, all with phenyl moiety, exhibited very high weed control activity, but caused severe phytotoxicity on transplanted rice exhibiting little selectivity between rice and weeds.
DPX-F5384, with $2-\mathrm{CO}_{2} \mathrm{CH}_{3}$ substituted benzyl moiety, was highly active, 2-Cl substituted DPX-F5390 had very low activity. In contrast to the benzyl type derivatives, DPX-R5582, with $2-\mathrm{Cl}$ substituted phenoxy, had considerably high activity.

Among the sulfonylurea compounds exa mined, DPX-F5384 proved to have sufficient crop safety for rice. DPX-R5582 was relatively safe to rice but its safety margin was not broad enough. In addition, DPX-R5582 was not particularly active on Scirpus juncoides, one of the major weeds in rice paddies. DPX-F5384 was the best compound based on its high weed control activity and selective safety to rice.

\section{References}

1) Doig, R. I. and G. A. Carraro: DPX-T6376-A new broad spectrum cereal herbicide. Proc. Brit. Crop Prot. Conf. 1, 324 331 (1983).

2) Levitu, G., H. L. Ploeg, R. C. Weigel, Jr., and D. J. FitzGERALD: 2-chlor-N-[(4-methoxy-6-methyl-1, 3, 5-triazin-2-yl) amino-carbonyl] benzensulfonamide, a new herbicide. J. Agric. Food Chem. 29, 416 424 (1981).

3) Levitt, G.: Sulfonylureas-New high potency herbicides. Proc. 5th International Congress of Pesticide Chemistry (IUPAC), 1, 243 250 (19 82).

4) Palm, H. L., J. D. Riggleman and D. A. Allison: Worldwide review of the new cereal herbicideDPX-4189. Proc. Brit. Crop Prot. Conf. Weeds 1, $1 \sim 6$ (1980).

5) RAY, T. B.: The mode of action of Chlorsulfuron-A new herbicide for cereals. Pestic. Biochem. Physiol. 17, 10 17 (1982).

6) Sweetser, P. B., G.S. Schow and J.M. HutCHIson: Metabolism of Chlorsulfuron by plants: Biological basis for selectivity of a new herbicide for cereals. Pestic. Biochem. Physiol. 17, 18 23 (1982).

7) Yuyama T., S. Takeda, H. Watanabe, T. Asami, S. Peudpaichit, J. L. Malassa and P. Heiss: DPX-F5384-A new broad spectrum rice herbicide. Proc. 9th. APWSS Conf. (Suppl.), $554 \sim 559$ (1983).

(Received May 8, 1985) 
数種スルホニルウレア化合物よりの水稲用除草剂の選抜

武田俊司・湯山 猛 デュポン ジャパン

R.C. Ackerson デュポン農薬事業部

R. C. Weigel テネシー大学植物学部

摘 要

スルホニルウレア化合物のうち, DPX-F5384 とその類縁化合物について，イネに対する選択性および水田雑草に 対する除草活性を比較検討した。その結果は下記のように要約できた。

1. 2- $\mathrm{CO}_{2} \mathrm{CH}_{3}$ の置換をもつスルホニルウレア誘導体, DPX-F5384 (benzyl group), DPX-T6375 (phenyl group）について, イネ, ハクサイの種子およびウリカワの塊茎を供試して, ペトリー四試験を行い, その初期生育 への影響を調べた。その結果，DPX-F5384 はイネと他の 2 植物の間で，高い選択性が認められたが，DPX-T6375 の選択性は相対的に低かった。

2. DPX-F5384 とその類縁化合物の除草活性とイネに対する安全性について, 水田状態のポットで比較検討した。 スルホニルウレア化合物の構造中に, phenyl 部分をもつ DPX-W4515, T6375,W4189, T6376 は, いずれも高い 除草活性を示したけれども，イネに対して強い薬害をひき起し，イネと雑草との間の選択性は小さかった。

3. 2- $\mathrm{CO}_{2} \mathrm{CH}_{3}$ 置換 benzyl タイプの DPX-F5384 は, 除草活性も高くイネに対する安全幅も十分認められた。 しかしながら，2-Cl 置換 benzyl 構造の DPX-F5390 の活性は著るしく低かった。また，2-Cl 置換 Phenoxy タ イプである DPX-R5582 の活性は，DPX-F5390 よりも，かなり高かったが，DPX-F5384 に比較すると低く，特 に水田の重要雑草であるホタルイに対する防除効果が不十分であり，イネに対する安全幅む狭かった。

以上の結果から, DPX-F5384 は, その高い除草活性とイネに対する選択的安全性によって，スルホニルウレア誘 導体の中で最適の水稲除草剤であると結論された。 